\title{
STUDY OF PERIPHERAL NEUROPATHY IN CHILDREN WITH TYPE 1 DIABETES MELLITUS AT ZAGAZIG UNIVERSITY HOSPITALS
}

\author{
Mohamed Elsayed Amer ${ }^{1}$, Hossam Mostafa Kamal ${ }^{1}$ and Ahmed Galal Siam ${ }^{1}$ \\ ${ }^{1}$ Department of Pediatrics, Faculty of Medicine, Zagazig University, Zagazig, Egypt
}

Corresponding author

Mohamed ElsayedAmer

01111818552

Abu_amer1979@yahoo.com

\begin{abstract}
Background: Diabetic peripheral neuropathy (DPN) plays a key role in morbidity and mortality in patients with type 1 and type 2 diabetes mellitus. The study was designed to assess frequency of diabetic peripheral neuropathy among the diabetic children and to evaluate the role of nerve conduction study (NCS) in diagnosis of DPN in children with type 1diabetes mellitus in comparison to neurological examination.

Subjects and methods: A cross sectional study was conducted in Pediatrics Department, Zagazig University Hospitals. Forty type-1 diabetic children were subjected to complete history taking, complete general and full neurological examination, Michigan Neuropathy Screening Instrument (MNSI), laboratory investigations and NCS.

Results: The estimated frequency of diabetic peripheral neuropathy was $42.5 \%$ among the diabetic children. We found a statistically significant moderate agreement between (NCS) and Michigan Neuropathy Screening Instrument, Kappa $=0.564(95 \% \mathrm{CI}, 0.321$ to 0.807$),(P<.001)$. The percent of children with microalbuminuria, fairly and poorly controlled diabetes was statistically significantly higher in PN-children than non PN-children $(P<.05)$.Duration of diabetes was the most important factor in prevalence of PNP (odds ratio=2.1 [95\% CI 1.3 to 3.4]).

Conclusion: NCS are the gold-standard method for the detection of subclinical DN which is frequent in diabetic children .
\end{abstract}

Keywords :Type 1 diabetes, Childhood diabetes, Diabetic neuropathy, Nerve conduction studies

\section{INTRODUCTION}

C hildhood diabetes has many forms including rare conditions, such as, neonatal diabetes, chronic disease associated (e.g. with cystic fibrosis) and monogenic diabetes (e.g. maturity onset diabetes of the young). The most common forms of diabetes are, Type 1 and Type 2 diabetes ${ }^{[1]}$.

Insulin-dependent diabetes mellitus (IDDM), type 1 diabetes (T1DM), is a classic example of a $\mathrm{T}$ cell-mediated autoimmune disease characterized by selective destruction of pancreatic $\beta$ cells leads to increased blood sugar levels ${ }^{[2,3] \text {. }}$

The reported incidence of childhood T1DM differs from 0.1 to 40.9 per 100,000 annually worldwide and the rate is increasing over time. The majority of children with diabetes present between 10 and 20 years of age ${ }^{[4-6]}$.

Diabetic neuropathy (DN) is a major complication of T1DM. This term usually points to polyneuropathy and can be categorized into two broad subclinical and clinical stages ${ }^{[7]}$.

It is the commonest form of neuropathy and may affect about half of all patients with diabetes (DM), causing considerable morbidity and mortality and resulting in a giant economic burden ${ }^{[8] \text {. }}$

Diabetic neuropathy refers to the presence of symptoms and/or signs of peripheral nerve dysfunction due to diabetes [9].

Other potential causes, such as vitamin deficiency, infection, inflammatory, toxic, metabolic, autoimmune, paraneoplastic, or inherited neuropathy, should be excluded [10].

Though evident diabetic neuropathy is seldom present in diabetic children and adolescents, subclinical diabetic neuropathy has been assessed to occur in about half of all children with T1DM with a duration of 5 
years or longer and up to $25 \%$ of pediatric patients with newly diagnosed diabetes have abnormal findings on nerve conduction studies ${ }^{[11]}$.

Clinical assessment of DN is not sensitive enough to diagnose diabetic peripheral neuropathy and Nerve conduction velocity measurement is the gold standard for the assessment of diabetic peripheral neuropathy ${ }^{[12] .}$

The objective of conducting this study was to assess frequency of diabetic peripheral neuropathy among the diabetic children and to evaluate the role of NCS in diagnosis of DPN in diabetic children with type 1 diabetes mellitus in comparison to neurological examination.

\section{SUBJECTS AND METHODS}

The present study was a crosssectional one. Patients were selected from inpatient and outpatient Clinics of Pediatrics Department, Zagazig University Hospitalsbetween January 2016 and January 2018.The study was approved by the local ethics committee. Informed written consent was obtained from the parents.Forty children with clinically definite T1DM according to WHO classification ${ }^{[13]}$ were enrolled in the study as a comprehensive sample.

Their ages were 10 years or older. All diabetic children underwent detailed history taking and complete general and full neurological examination (mentality, coordination, cranial nerves, motor system (tone, power and reflexes), sensory system (superficial, deep, cortical and special sensation)) according to Meijer et al. ${ }^{[14]}$ and Michigan Neuropathy Screening Instrument (MNSI) ${ }^{[15] .}$ Nerve conduction studies were performed using Nihon KohdenNeuropack MEB-9102 EP EMG machine.

The following patients were excluded from the study; diabetic children with other causes of neuropathy such as uremia, collagen disease, nutritional, toxic, familial, etc....and diabetic children with evidence of other neuromuscular diseases such as myopathy or myasthenia Gravis. Routine laboratory investigations including (glycosylated hemoglobin (HBA1C), albumin creatinine ratio in urine and serum cholesterol) were carried out.

\section{STATISTICAL ANALYSIS}

Continuous data were presented as the Mean \pm SD (normally distributed). Normality was checked by Shapiro-Wilk test. Homogeneity of variances was checked by Leven's test. Categorical data were presented by the count and percentage. Cohen's Kappa is a measure of inter-rater agreement for categorical variables when there are two raters. Unpaired t-test is used to determine if a difference exists between the means of two independent groups on a continuous dependent variable. The chi-squared test or Fisher's Exact Test is used to discover if there is a relationship between two categorical variables as appropriate. The one-way analysis of variance (ANOVA) is used to determine whether there are any significant differences between the means of two or more independent (unrelated) groups on a continuous dependent variable. GamesHowell's post hoc test: is used for multiple comparisons between groups following ANOVA test if equal variances are not assumed. Binary logistic regression analysis is a multifactorial regression model used with a binary outcome. The differences were considered significant at $P<.05$. All statistical comparisons were two-tailed. All statistical calculations were carried out using Statistical Package of Social Science (SPSS), software version 24.0 (SPSS Inc., 2016).

\section{RESULTS}

Forty type-1 diabetic children were enrolled in the current study. Baseline characteristics and laboratory data are shown in table 1 and table 2 . The mean age was $12.5 \pm 1.6$ years, median age (12.5) and (range $10-15)$. Whereas mean diabetes duration was $4.8 \pm 2.2$ years, median duration (4.7) and (range 1.08-10),

The prevalence of diabetic peripheral neuropathy was $17(42.5 \%)$ among the studied diabetic children, while the frequency of subclinical peripheral nephropathy was in $8 / 17$ of DN-children. Regarding NCS , there was a highly statistically significant agreement between NCS and neurological assessment by (MNSI), $\kappa=0.564(95 \% \mathrm{CI}$, 0.321 to 0.807$),(P<.001)$. The strength of agreement was classified as moderate, as shown in table 3 . 
Amed M. et al

Subgroup analysis stratified according to diabetic peripheral neuropathy; PN) as diagnosed by nerve conduction studies

Diabetic children with peripheral neuropathy showed a non-statistically significant difference in age $(P>.05)$ but a statistically significantly longer duration of DM compared to non PN-children $(P<.05)$, as shown in table 4.

Regarding clinical evaluation of diabetic children, all diabetic children experienced pain, normal upper limb, and knee reflexes as well normal cranial nerves examination and no foot ulcers. The percent of sensory and autonomic dysfunction, hypotonia and ankle hyporeflexia was statistically significantly higher in PNchildren than non $\mathrm{PN}$-children $(P<.05)$ while the percent of $\mathrm{PN}$-children with muscle weakness was statistically significantly similar to non PN-children $(P>.05)$, as shown in table 5 and table 6.

Regarding laboratory findings of diabetic children, all diabetic children had normal serum cholesterol level. The percent of microalbuminuria was statistically significantly higher in PN-children than non PN-children $(P<.003)$. The percent of fairly and poorly controlled diabetic children was statistically significantly higher in PNchildren than non PN-children but the percent of diabetic children with good diabetic control was statistically significantly lower in PNchildren than non $\mathrm{PN}$-children $(P<.05)$, as shown in a table 7.

Duration of diabetes was the most important factor in prevalence of PNP (odds ratio $=2.1$ [95\% CI 1.3 to 3.4]).A logistic regression was performed to determine the effects of duration of DM on the likelihood that diabetic children have peripheral neuropathy. The logistic regression model was statistically significant, $\chi^{2}(1)=16.2$, $P<.001$. The model explained $45 \%$ (Nagelkerke $R^{2}$ ) of the variance and correctly classified $75 \%$ of cases. Increasing duration of DM was associated with an increased likelihood of having peripheral neuropathy. For every one year increase in the duration of $\mathrm{DM}$, the risk of peripheral neuropathy increases by 2.1 times among the diabetic children, as shown in a table 8 .
Zagazig University Medical Journals

\section{DISCUSSION}

Type 1 diabetes mellitus (T1DM) is the most common chronic endocrine disorder in childhood, which is usually discovered among children, adolescents and young adults [16].

Diabetic neuropathy is the main cause of neuropathy all over the world. It plays a key role in morbidity and mortality in patients with type 1 and type 2 diabetes mellitus [17].

Children and adolescents are at higher risk of long term complications due to the longer duration of T1DM ${ }^{[18]}$. However, DPN is often undiagnosed through the evaluation of clinical symptoms, clinical examination, electrodiagnostic studies, sensory testing and autonomic testing [19].

The present study revealed that the frequency of neuropathy in children with T1DM was $42.5 \%(17 / 40)$ as diagnosed by Nerve conduction studies (NCS) at Zagazig University Hospitals.

A study conducted by Moser and coworkers ${ }^{[20]}$ reported that of 151 youth with type 1 diabetes who were screened for peripheral neuropathy by (NCS), $11 \%$ were diagnosed with diabetic peripheral neuropathy (DPN).

The EURODIAB study (European Diabetes Prospective Complications Study) reported that the neuropathy prevalence was $28 \%$ at baseline ${ }^{\text {[21]. }}$

In the present study, the results showed for every one year increase in the duration of DM, the risk of peripheral neuropathy increases by 2.1 times. Additionally, $60 \%$ of our patients developed DP had DM more than five years.

Similarly, the present results are corroborated by findings of Hasani and coworkers [22] who conducted a crosssectional Iranian study on 500 diabetic children to evaluate the prevalence and possible risk-factors of PNP in children with T1DM, their observation revealed that duration of diabetes was the most important factor in prevalence of PNP (odds ratio $=1.33$ [95\% CI 1.15 to 1.5$]$ ).

Likewise, a lot of studies introduced the diabetes duration as a chief factor in developing $\mathrm{PN}^{[23-25]}$. 
According to the results of the present work, the agreement between NCS and the clinical assessment based on MNSI was moderate. The frequency of subclinical cases among the truly DN-children was 47\% (8/17). NCS picked up eight subclinical cases that were missed from the clinical diagnosis. These findings were supported by Ghaemi et al. [7]in their prospective study on 50 diabetic children and young adults, reported that the agreement between NCS and the clinical signs was fair (Kappa coefficients=0.29).

The currenet results are in agreement with Hirschfeld et al. ${ }^{[26]}$ in their a prospective phase III diagnostic study on a total of 88 children with Type 1 diabetes mellitus who informed that $49 \%$ of children had abnormal nerve conduction study.

Nerve conduction studies (NCS) are widely considered the gold standard and most reliable method in the diagnosis of DN, where abnormalities in the nerve conduction velocities (NCV) may be noted even in the early asymptomatic stage of DN. NCS are electrophysiological studies with excellent reproducibility, and are the first objective quantitative indication of $\mathrm{DN}^{[18,27,28]}$.

Clinical neuropathy is relatively uncommon in pediatric populations, although subclinical neuropathy is commonly seen, particularly in adolescents. Peripheral DN involves impairment of the large and/or small nerve fibers, and can be diagnosed by various methods [18].

In the present research, the frequency of subclinical peripheral nephropathy was in $47 \%(8 / 17)$ of DN-children. Similarly, Toopchizadeh et al. [29] evaluated the frequency of PN in children and adolescents with T1DM in their cross-section study and found subclinical peripheral nephropathy was in $57.5 \%(23 / 40)$ of patients.

The findings of the current research showed that all patients with DN symptomatizing pain and $41 \%$ showed weakness; about 82,88 and $29 \%$ showed numbness, tingling and autonomic dysfunction respectively but their sensory examination revealed that deep sensations were mostly affected as position and movement and vibration sensations were reduced in approximately $70 \%$ of patients.
In the current research, the sensory manifestations are the most common presentation of neuropathy in diabetic patients. Sensory nerve damage occurs earlier than motor nerve damage, perhaps due to thinner and longer nerves in sensory nerves, which could be more vulnerable to metabolic insults ${ }^{[30,31]}$.

Similar to the present results, a study of Boulton et al. ${ }^{[9]}$ informed that sensorimotor neuropathy, particularly distal sensory diabetic polyneuropathy is the most common presentation of neuropathy in diabetes, and more than $50 \%$ of patients may experience symptoms most frequently burning pain, electrical or stabbing sensations, paresthesia, hyperesthesia, and deep aching pain.

This study corroborates the fact that "ankle reflex is a powerful screening tool with high sensitivity and negative predictive value, but a combination of ankle reflex and vibration sense has superior sensitivity and specificity compared with either of them done alone for the detection of DPN in clinical settings" ${ }^{[32]}$. The present results showed that ankle hyporeflexia was the most frequent sign as well as vibration sensations were reduced in approximately $70 \%$ of DPN-children patients.

The present results revealed that all DPN diabetic children were free from cranial nerves affection. Geloneck et al. [33] conducted a retrospective, consecutive cohort study on a total of 370 children to assess ocular complications of diabetes in children and young adults and they noted that only one patient had a paralytic strabismus from an abducent nerve palsy, which resolved spontaneously.

In the current research, about $59 \%$ of children with DN, as diagnosed by NCS, had poor glycemic control according to $\mathrm{HbA1C}$ while $9 \%$ of children without DN had poor glycemic control. Ghaemi et al. ${ }^{[7]}$ in their prospective study on 50 diabetic children and young adults reported that poor glycemic control is one of the most important risk factors for the development of PN.

Diabetic kidney disease (DKD) is the leading cause of end-stage renal disease world-wide. Microalbuminuria has been 
recommended as the first clinical sign of DKD ${ }^{[34,35] \text {. }}$

According to the findings of the current work, all non-PN diabetic children were free from microalbuminuria, whereas approximately $65 \%$ of PN diabetic children had microalbuminuria. This could be explained by the mutual mechanisms and the common risk factors of the diabetic neuropathy and nephropathy, exactly; poor diabetic control and duration of diabetes ${ }^{\text {[36- }}$ 38].

The findings of the current work, all non-PN diabetic children had normal serum cholesterol level. Ghaemi et al. study [7] informed no association between hyperlipidemia and DPN, however; a previous studies have suggested an association between hyperlipidemia and DPN $[39,40]$.

Table 1 Baseline characteristics of type 1 diabetic children

\begin{tabular}{|l|c|}
\hline Baseline characteristics & \\
\hline Age (years) & $12.5 \pm 1.6$ \\
\hline Mean \pm SD & $12.5(10-15)$ \\
\hline Median(Range) & $4.8 \pm 2.2$ \\
\hline Duration of DM (years) & $4.7(1.08-10)$ \\
\hline Mean \pm SD & \\
\hline Median(Range) & \\
\hline
\end{tabular}

Total number $=40$

Table 2 Laboratory findings of type 1 diabetic children

\begin{tabular}{|l|c|}
\hline Laboratory findings & \\
\hline Serum cholesterol, $n,(\%)$ & $40(100 \%)$ \\
\hline Normal & $0(0.0 \%)$ \\
\hline Abnormal & \\
\hline Urine albumin/creatinine ratio, $n,(\%)$ & $34(85 \%)$ \\
\hline Normal $(<30 \mathrm{mg} / \mathrm{g})$ & $6(15 \%)$ \\
\hline Microalbuminuria $(30-300 \mathrm{mg} / \mathrm{g})$ & $19(47.5 \%)$ \\
\hline HbA1c, $n,(\%)$ & $13(32.5 \%)$ \\
\hline Good $(<6.5 \%)$ & $8(20 \%)$ \\
\hline Fair $(6.5-7.5 \%)$ & \\
\hline Poor $(>7.5 \%)$ & \\
\hline
\end{tabular}

Total number $=40$ 
Table 3 Inter-rater agreement (kappa) between Nerve conduction study (NCS) and Michigan Neuropathy Screening Instrument (MNSI)

\begin{tabular}{|l|c|c|c|}
\hline \multirow{2}{*}{$\begin{array}{l}\text { Michigan Neuropathy } \\
\text { Screening Instrument } \\
\text { MNSI) }\end{array}$} & DN & Non-DN & \multirow{2}{*}{ Nerve conduction study (NCS) } \\
\cline { 2 - 3 } DN & 9 & 0 & $9(22.5 \%)$ \\
\hline Non-DN & $\begin{array}{c}8 \\
\text { (subclinical DN) }\end{array}$ & 23 & $31(77.5 \%)$ \\
\hline$n, \%$ & $17(42.5 \%)$ & $23(57.5 \%)$ & 40 \\
\hline Cohen's Kappa & \multicolumn{3}{|c}{0.321 to 0.807} \\
\hline $95 \%$ CI & \multicolumn{3}{|c|}{0.364} \\
\hline
\end{tabular}

Table 4 Baseline characteristics in PN-children and non PN-children

\begin{tabular}{|c|c|c|c|c|}
\hline \multirow[t]{2}{*}{ Variables } & PN-children & Non PN-children & \multirow[t]{2}{*}{ Significance test } & \multirow[t]{2}{*}{$P$-value } \\
\hline & $n=17$ & $n=23$ & & \\
\hline Age (years) & & & \multirow{2}{*}{$\begin{array}{l}\text { Unpaired t- } \\
\text { test }=1.6\end{array}$} & \multirow[t]{2}{*}{.12} \\
\hline Mean \pm SD & $12.9 \pm 1.3$ & $12.1 \pm 1.7$ & & \\
\hline $\begin{array}{l}\text { Duration of DM } \\
\text { (years) }\end{array}$ & & & \multirow[t]{2}{*}{$\begin{array}{l}\text { Unpaired } t- \\
\text { test }=3.6\end{array}$} & \multirow[t]{2}{*}{$.001 * * *$} \\
\hline Mean \pm SD & $2.7 \pm 0.5$ & $1.9 \pm 0.9$ & & \\
\hline
\end{tabular}

Table 5 Sensory and autonomic symptoms in PN-children and non PN-children

\begin{tabular}{|c|c|c|c|c|}
\hline \multirow[t]{2}{*}{ Variables } & PN-children & Non PN-children & \multirow{2}{*}{$\begin{array}{l}\text { Significance } \\
\text { test }\end{array}$} & \multirow[t]{2}{*}{$P$-value } \\
\hline & $n=17$ & $n=23$ & & \\
\hline Weakness, $n,(\%)$ & & & \multirow{3}{*}{$\begin{array}{l}\text { Fisher's } \\
\text { Exact Test }\end{array}$} & \multirow[t]{3}{*}{$.001 * * *$} \\
\hline Present & $7(41.2 \%)$ & $0(0.0 \%)$ & & \\
\hline Absent & $10(58.8 \%)$ & $23(100 \%)$ & & \\
\hline Numbness, $n,(\%)$ & & & \multirow[t]{3}{*}{$\chi^{2}=8.9$} & \multirow[t]{3}{*}{$.003 * *$} \\
\hline Present & $14(82.4 \%)$ & $8(34.8 \%)$ & & \\
\hline Absent & $3(17.6 \%)$ & $15(65.2 \%)$ & & \\
\hline Tingling, $n,(\%)$ & & & \multirow[t]{3}{*}{$\chi^{2}=11.4$} & \multirow[t]{3}{*}{$.001 * * *$} \\
\hline Present & $15(88.2 \%)$ & $8(34.8 \%)$ & & \\
\hline Absent & $2(11.8 \%)$ & $16(65.2 \%)$ & & \\
\hline $\begin{array}{l}\text { Autonomic dysfunction, } n \text {, } \\
(\%)\end{array}$ & & & \multirow[t]{3}{*}{$\begin{array}{c}\text { Fisher's } \\
\text { Exact Test }\end{array}$} & \multirow[t]{3}{*}{$.009 * *$} \\
\hline Present & $5(29.4 \%)$ & $0(0.0 \%)$ & & \\
\hline Absent & $12(70.6 \%)$ & $23(100.0 \%)$ & & \\
\hline
\end{tabular}


Table 6 Sensory examination (superficial and deep sensation) of PN-children and non PN-children

\begin{tabular}{|c|c|c|c|c|}
\hline \multirow[t]{2}{*}{ Variables } & PN-children & Non PN-children & \multirow{2}{*}{$\begin{array}{l}\text { Significance } \\
\text { test }\end{array}$} & \multirow[t]{2}{*}{$P$-value } \\
\hline & $n=17$ & $n=23$ & & \\
\hline Pain, $n,(\%)$ & & & \multirow[t]{3}{*}{$\chi^{2}=15.7$} & \multirow[t]{3}{*}{$<.001 * * *$} \\
\hline Normal & $8(47.1 \%)$ & $23(100 \%)$ & & \\
\hline Reduced & $9(52.9 \%)$ & $0(0.0 \%)$ & & \\
\hline Touch, $n,(\%)$ & & & \multirow{3}{*}{$\begin{array}{c}\text { Fisher's } \\
\text { Exact Test }\end{array}$} & \multirow[t]{3}{*}{$.001 * * *$} \\
\hline Normal & $9(52.9 \%)$ & $23(100.0 \%)$ & & \\
\hline Reduced & $8(47.1 \%)$ & $0(0.0 \%)$ & & \\
\hline Temperature, $n,(\%)$ & & & \multirow{3}{*}{$\begin{array}{c}\text { Fisher's } \\
\text { Exact Test }\end{array}$} & \multirow[t]{3}{*}{$.001 * * *$} \\
\hline Normal & $10(58.8 \%)$ & $23(100.0 \%)$ & & \\
\hline Reduced & $7(41.2 \%)$ & $0(0.0 \%)$ & & \\
\hline Vibration, $n,(\%)$ & & & \multirow[t]{3}{*}{$\chi^{2}=16.5$} & \multirow[t]{3}{*}{$<.001 * * *$} \\
\hline Normal & $5(29.4 \%)$ & $21(91.3 \%)$ & & \\
\hline Reduced & $12(70.6 \%)$ & $2(8.7 \%)$ & & \\
\hline $\begin{array}{l}\text { Position and movement, } n \text {, } \\
(\%)\end{array}$ & & & \multirow[t]{3}{*}{$\chi^{2}=11.5$} & \multirow[t]{3}{*}{$.001 * * *$} \\
\hline Normal & $5(29.4 \%)$ & $19(82.6 \%)$ & & \\
\hline Lost & $12(70.6 \%)$ & $4(17.4 \%)$ & & \\
\hline
\end{tabular}

Table 7 Laboratory findings of PN-children and non PN-children

\begin{tabular}{|c|c|c|c|c|}
\hline \multirow[t]{2}{*}{ Variables } & PN-children & $\begin{array}{l}\text { Non PN- } \\
\text { children }\end{array}$ & \multirow[t]{2}{*}{$\begin{array}{c}\text { Fisher's Exact } \\
\text { Test }\end{array}$} & \multirow[t]{2}{*}{$P$-value } \\
\hline & $n=17$ & $n=23$ & & \\
\hline $\begin{array}{l}\text { Urine albumin/creatinine ratio, } n \text {, } \\
(\%)\end{array}$ & & & \multirow[t]{3}{*}{$\begin{array}{c}\text { Fisher's Exact } \\
\text { Test }\end{array}$} & \multirow[t]{3}{*}{$.003 * *$} \\
\hline Normal $(<30 \mathrm{mg} / \mathrm{g})$ & $11(64.7 \%)$ & $23(100.0 \%)$ & & \\
\hline $\begin{array}{l}\text { Microalbuminuria } \\
(30-300 \mathrm{mg} / \mathrm{g})\end{array}$ & $6(35.3 \%)$ & $0(0.0 \%)$ & & \\
\hline HbA1c, $n,(\%)$ & & & \multirow[t]{4}{*}{21.8} & \multirow[t]{4}{*}{$<.001 * * *$} \\
\hline Good $(<6.5 \%)$ & $1(5.9 \%)$ & $18(78.3 \%)$ & & \\
\hline Fair $(6.5-7.5 \%)$ & $10(58.8 \%)$ & $3(13 \%)$ & & \\
\hline Poor $(>7.5 \%)$ & $6(35.3)$ & $2(8.7 \%)$ & & \\
\hline
\end{tabular}


Table 8 Logistic regression predicting likelihood of peripheral neuropathy based on duration of DM in type 1 diabetic children

\begin{tabular}{|l|c|c|c|c|c|}
\hline Variable & $\beta$ & S.E & Wald & $\begin{array}{c}\text { Odds ratio (95\% } \\
\text { CI) }\end{array}$ & $P$-value \\
\hline $\begin{array}{l}\text { Duration of DM } \\
\text { (years) }\end{array}$ & 0.76 & 0.24 & 9.9 & $2.1(1.3-3.4)$ & $\mathbf{. 0 0 2} * *$ \\
\hline Constant & -4.1 & 1.3 & 10.2 & \\
\hline$* *$ highly-significant $(P<.01), \beta$, Regression coefficients, S.E, standard error \\
\hline
\end{tabular}

\section{CONCLUSION}

In conclusion, as subclinical peripheral neuropathy is frequent in diabetic children and young adult. There is a critical need for further expanding the use of NCS to detect subclinical DN earlier.

Nerve conduction studies (NCS) are the gold-standard method for the detection of subclinical DN.

Firm blood glucose control and periodic neurological examinations are the best approaches to prevent PN.

\section{REFERENCES}

[1] Cizza G, Brown RJ, Rother KI. Rising incidence and challenges of childhood diabetes. A mini review. J Endocrinol Invest 2012;35:541-6.

[2] Michels A, Zhang L, Khadra A, Kushner JA, Redondo MJ, Pietropaolo M. Prediction and prevention of type 1 diabetes: update on success of prediction and struggles at prevention. Pediatr Diabetes 2015;16:46584.

[3] Saberzadeh-Ardestani B, Karamzadeh R, Basiri M, Hajizadeh-Saffar E, Farhadi A, Shapiro AMJ, et al. Type 1 Diabetes Mellitus: Cellular and Molecular Pathophysiology at A Glance. Cell J 2018;20:294-301.

[4] DIAMOND Project Group. Incidence and trends of childhood Type 1 diabetes worldwide 1990-1999. Diabet Med 2006;23:857-66.

[5] Craig ME, Hattersley A, Donaghue KC. Definition, epidemiology and classification of diabetes in children and adolescents. Pediatr Diabetes 2009;10 Suppl 1:3-12.

[6] Shera AS, Miyan Z, Basit A, Maqsood A, Ahmadani MY, Fawwad A, et al. Trends of type 1 diabetes in Karachi, Pakistan. Pediatr Diabetes 2008;9:401-6.

[7] Ghaemi N, Hasanabadi H, Ashrafzadeh F, Sarvari S, Rahimi H, Hashemian S. Peripheral neuropathy in children and adolescents with insulin-dependent diabetes mellitus. Iran J Child Neurol 2018;12:83-90.

[8] Vinik A, Casellini C, Nevoret M. Diabetic Neuropathies. In: De Groot L, Chrousos G, Dungan K, editors. Endotext [Internet], Endotext [Internet]. South Dartmouth (MA): MDText.com, Inc; 2015.

[9] Boulton AJM, Vinik AI, Arezzo JC, Bril V, Feldman EL, Freeman R, et al. Diabetic neuropathies: a statement by the American Diabetes Association. Diabetes Care 2005;28:956-62.

[10] Freeman R. Not all neuropathy in diabetes is of diabetic etiology: differential diagnosis of diabetic neuropathy. Curr Diab Rep 2009;9:423-31.

[11] Mah JK, Pacaud D. Diabetic neuropathy in children. Handb Clin Neurol 2014;126:12343.

[12]Walter-Höliner I, Barbarini DS, Lütschg J, Blassnig-Ezeh A, Zanier U, Saely $\mathrm{CH}$, et al. High Prevalence and Incidence of Diabetic Peripheral Neuropathy in Children and Adolescents With Type 1 Diabetes Mellitus: Results From a Five-Year Prospective Cohort Study. Pediatr Neurol 2018;80:51-60.

[13] World Health Organization. Definition, Diagnosis and Classification of Diabetes Mellitus. 1999.

[14] Meijer JW, van Sonderen E, Blaauwwiekel EE, Smit AJ, Groothoff JW, Eisma WH, et al. Diabetic neuropathy examination: a hierarchical scoring system to diagnose distal polyneuropathy in diabetes. Diabetes Care 2000;23:750-3.

[15] Herman WH, Pop-Busui R, Braffett BH, Martin CL, Cleary PA, Albers JW, et al. Use of the Michigan Neuropathy Screening Instrument as a measure of distal symmetrical peripheral neuropathy in Type 1 diabetes: results from the Diabetes Control and Complications Trial/Epidemiology of Diabetes Interventions and Complications. Diabet Med 2012;29:937-44.

[16] Bluestone JA, Herold K, Eisenbarth G. Genetics, pathogenesis and clinical 
interventions in type 1 diabetes. Nature 2010;464:1293-300.

[17] Said G. Diabetic neuropathy. Handb Clin Neurol 2013;115:579-89.

[18] Louraki M, Karayianni C, KanakaGantenbein C, Katsalouli M, Karavanaki K. Peripheral neuropathy in children with type 1 diabetes. Diabetes Metab 2012;38:281-9.

[19] Glastras SJ, Mohsin F, Donaghue KC. Complications of Diabetes Mellitus in Childhood. Pediatr Clin North Am 2005;52:1735-53.

[20] Moser JT, Langdon DR, Finkel RS, Ratcliffe SJ, Foley LR, Andrews-Rearson ML, et al. The evaluation of peripheral neuropathy in youth with type 1 diabetes. Diabetes Res Clin Pract 2013;100:e3-6.

[21] Tesfaye S, Chaturvedi N, Eaton SEM, Ward JD, Manes C, Ionescu-Tirgoviste C, et al. Vascular Risk Factors and Diabetic Neuropathy. N Engl J Med 2005;352:34150.

[22] Hasani N, Khosrawi S, Hashemipour M, Haghighatiyan M, Javdan Z, Taheri MH, et al. Prevalence and related risk-factors of peripheral neuropathy in children with insulin-dependent diabetes mellitus. J Res Med Sci 2013;18:132-6.

[23] Malgrange D, Richard JL, Leymarie F, French Working Group On The Diabetic Foot. Screening diabetic patients at risk for foot ulceration. A multi-centre hospital-based study in France. Diabetes Metab 2003;29:261-8.

[24] Booya F, Bandarian F, Larijani B, Pajouhi M, Nooraei M, Lotfi J. Potential risk factors for diabetic neuropathy: a case control study. BMC Neurol 2005;5:24.

[25] Weintrob N, Amitay I, Lilos P, Shalitin S, Lazar L, Josefsberg Z. Bedside neuropathy disability score compared to quantitative sensory testing for measurement of diabetic neuropathy in children, adolescents, and young adults with type 1 diabetes. J Diabetes Complications n.d.;21:13-9.

[26] Hirschfeld G, von Glischinski M, Knop C, Wiesel T, Reinehr T, Aksu F, et al. Difficulties in screening for peripheral neuropathies in children with diabetes. Diabet Med 2015;32:786-9.

[27] Lacomis D. Small-fiber neuropathy. Muscle and Nerve 2002;26:173-88.

[28] Tesfaye S, Boulton AJM, Dyck PJ, Freeman R, Horowitz M, Kempler P, et al. Diabetic neuropathies: update on definitions, diagnostic criteria, estimation of severity, and treatments. Diabetes Care 2010;33:2285-93.
[29] Toopchizadeh V, Shiva S, Khiabani N-Y, Ghergherechi R. Electrophysiologic pattern and prevalence of subclinical peripheral neuropathy in children and adolescents with type I diabetes mellitus in Iran. Saudi Med J 2016;37:299-303.

[30] Pasnoor M, Dimachkie MM, Kluding P, Barohn RJ. Diabetic neuropathy part 1: overview and symmetric phenotypes. Neurol Clin 2013;31:425-45.

[31] Won JC, Kim SS, Ko KS, Cha B-Y. Current status of diabetic peripheral neuropathy in Korea: report of a hospital-based study of type 2 diabetic patients in Korea by the diabetic neuropathy study group of the korean diabetes association. Diabetes Metab J 2014;38:25-31.

[32] Shehab DK, Al-Jarallah KF, Abraham M, Mojiminiyi OA, Al-Mohamedy $\mathrm{H}$, Abdella NA. Back to basics: ankle reflex in the evaluation of peripheral neuropathy in type 2 diabetes mellitus. QJM 2012;105:315-20.

[33] Geloneck MM, Forbes BJ, Shaffer J, Ying G, Binenbaum G. Ocular Complications in Children with Diabetes Mellitus. Ophthalmology 2015;122:2457-64.

[34] Chen C, Wang C, Hu C, Han Y, Zhao L, Zhu $\mathrm{X}$, et al. Normoalbuminuric diabetic kidney disease. Front Med 2017;11:310-8.

[35] Gäckler D, Jäkel S, Fricke L, Reinsch B, Fischer F. Diabetes und Niere. DMW - Dtsch Medizinische Wochenschrift 2013;138:949_ 55 .

[36] Veresiu AI, Bondor CI, Florea B, Vinik EJ, Vinik AI, Gâvan NA. Detection of undisclosed neuropathy and assessment of its impact on quality of life: a survey in 25,000 Romanian patients with diabetes. J Diabetes Complications 2015;29:644-9.

[37] Vinik A, Pittenger G, McNitt P, Stansberry K. Diabetic neuropathies. An overview of clinical aspects, pathogenesis and treatment. In: Le Roith D, Taylor S, Olefsky J, editors. Diabetes Mellit. A Fundam. Clin. Text. 2 nd, Philadelphia: Lipincott, Williams \& Wilkins; 2000, p. 910-934.

[38] Ješić M, Sajić S, Ješić M, Kostić M, PecoAntić A, Vujnović Z, et al. Microalbuminuria in relation to metabolic control and blood pressure in adolescents with type 1 diabetes. Arch Med Sci 2011;6:1037-41.

[39] Ji N, Zhang N, Ren Z-J, Jia K-B, Wang L, Ni $\mathrm{J}-\mathrm{X}$, et al. Risk factors and pain status due to diabetic neuropathy in chronic long-term diabetic patients in a Chinese urban population. Chin Med J (Engl) 2012;125:4190-6. 
Amed M. et al

[40] Jaiswal M, Divers J, Dabelea D, Isom S, Bell RA, Martin CL, et al. Prevalence of and Risk Factors for Diabetic Peripheral Neuropathy
Zagazig University Medical Journals

in Youth With Type 1 and Type 2 Diabetes: SEARCH for Diabetes in Youth Study. Diabetes Care 2017;40:1226-32.

How to cite this article: Amer $\mathrm{M}$, Kamal $\mathrm{H}$ and Siam A. study of Peripheral Neuropathy in Children with Type 1 Diabetes Mellitus at Zagazig University Hospitals.ZUMJ 2019; 25 (1); 116125. 